\title{
Evaluation of Forest Fire Danger Indexes for Eucalypt Plantations in Bahia, Brazil
}

\author{
Larissa Alves Secundo White, ${ }^{1}$ Benjamin Leonardo Alves White, ${ }^{2}$ \\ and Genésio Tâmara Ribeiro ${ }^{1}$ \\ ${ }^{1}$ Departamento de Engenharia Florestal, Universidade Federal de Sergipe, Avenida Marechal Rondon, s/n, Rosa Elze, \\ 49100-000 São Cristóvão, SE, Brazil \\ ${ }^{2}$ Laboratório GEOPLAN, Universidade Federal de Sergipe, Avenida Marechal Rondon, s/n, Rosa Elze, \\ 49100-000 São Cristóvão, SE, Brazil \\ Correspondence should be addressed to Benjamin Leonardo Alves White; benjmk@ig.com.br
}

Received 14 April 2015; Revised 18 June 2015; Accepted 18 June 2015

Academic Editor: Piermaria Corona

Copyright (c) 2015 Larissa Alves Secundo White et al. This is an open access article distributed under the Creative Commons Attribution License, which permits unrestricted use, distribution, and reproduction in any medium, provided the original work is properly cited.

\begin{abstract}
A Forest Fire Danger Index is a valuable tool in forest fire prevention and firefight because it grades fire occurrence possibility on a daily basis. Six Fire Danger Indexes were tested for accuracy based on forest fire occurrence in eucalyptus plantations of the north coast of Bahia, Brazil. They are Angstron, Nesterov, Telicyn Logarithmic Index, Monte Alegre, Rodríguez and Moretti, and Modified Monte Alegre. The results were analyzed using two parameters of the Heidke Skill Score test: Skill Score index and Percentage of Success. The Telicyn Logarithmic Index proved to be the most accurate for the study area.
\end{abstract}

\section{Introduction}

Every year, forest fires are responsible for economic impact and local biodiversity loss in almost every country in the world [1]. In Brazil from 1998 to 2002, 85 thousand hectares burned, including 13.5 thousand hectares of eucalyptus [2]. Also in Brazil, between the periods of 1983-1987, 1994-1997, forest fires destroyed areas of 134 thousand and 265 thousand hectares, respectively. And in 1963, in the Brazilian state of Paraná, one of the worst fires occurred, devastated 2 million hectares and killed 110 people [3, 4].

Fires break dynamic equilibrium in a forest and cause increasing susceptibility to erosion, mudslides, and pests (particularly ants and termites). They damage infrastructure, melting electrical and communication wires, block roads with burning debris, and pollute the atmosphere with $\mathrm{CO}_{2}$. Wildlife, livestock, pets, and humans in the area suffer respiratory complications, burns, and death [5-12].

Therefore, the need for more effective fire prevention is obviously urgent, particularly in regions more susceptible, due to the type of vegetation, climatic conditions $[13,14]$, and the amount of human disturbance [15], and even more so in those regions that represent conservation or economic interest [16].

With this goal in mind, in the middle of the 20th century, Angstron and Nesterov developed Fire Danger Indexes that predict an area's fire susceptibility based on weather conditions. The success of these tools has inspired many others to try to develop more accurate indexes for their own regions. The indexes are so important because they help determine the best time to intensify preventive measures, such as employing more park rangers; raising public awareness; organizing and training volunteers; increasing forest surveillance; constructing firebreaks; and choosing the best days to safely reduce the fuel loads with controlled burnings $[17,18]$.

Unfortunately, in Brazil, there are a few national preventive educational campaigns against forest fire. Also, there is no Forest Fire Danger Index that is especially calibrated for the entire country, as can be found in other countries such as Portugal, Spain, Australia, Canada, and the USA [1923]. Regionally though, the Monte Alegre Index (FMA) and the Modified Monte Alegre Index (FMA+) were developed 


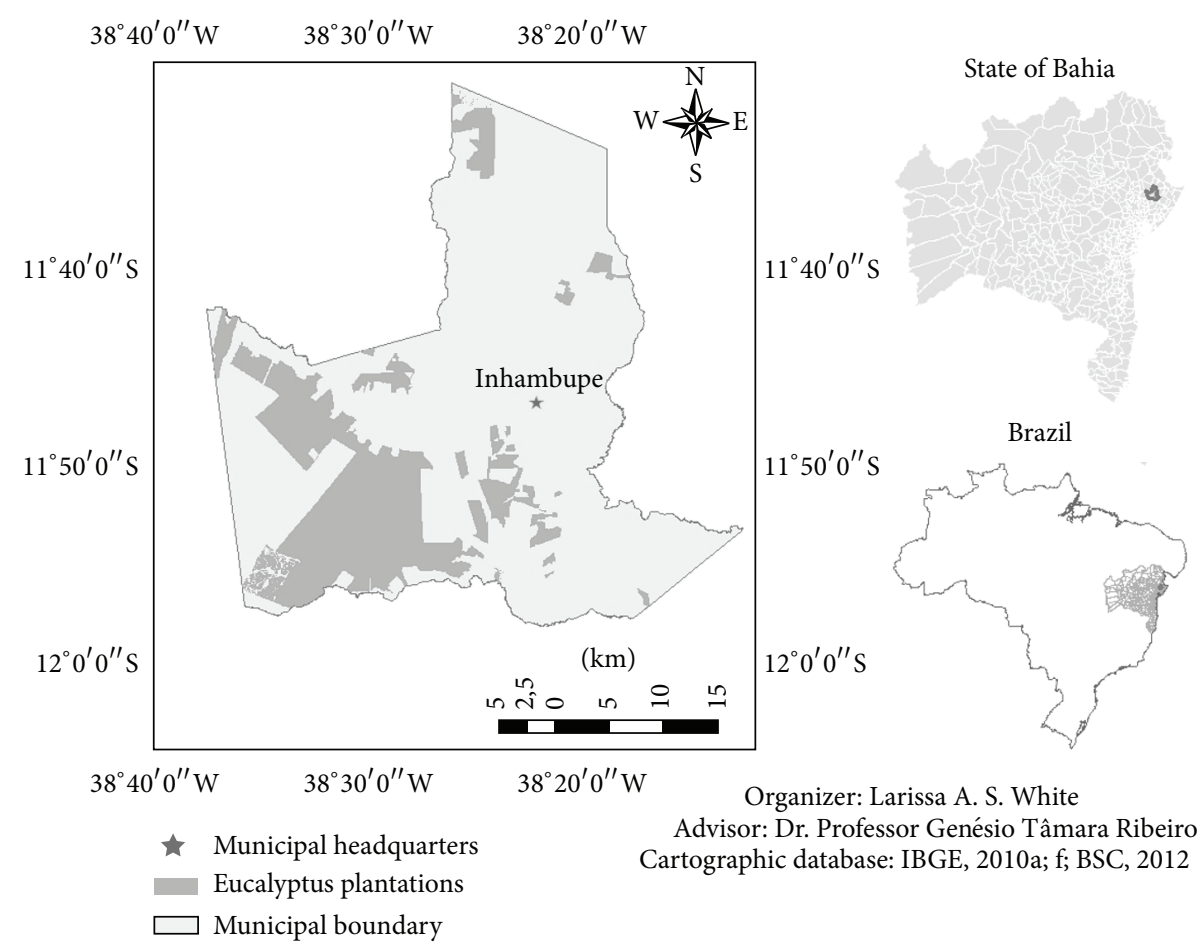

FIGURE 1: Focused area including the eucalypt plantations of the Bahia Specialty Cellulose company.

especially for the south and southwest regions of the country and presented good results $[24,25]$. However, few studies have been directed to the northeast region (e.g., [13, 26-28]), where this study is based.

So, aiming at helping diminish losses caused by fire in eucalyptus plantations at the study site, this work evaluated the forecast efficiency of the six most used Fire Danger Indexes in Brazil: Telicyn Logarithmic; Angstron; Nesterov; Rodríguez and Moretti; FMA; and FMA+ [26, 27, 29-32]. Although there exist other Fire Danger Indexes commonly used in other countries, such as the Canadian Fire Weather Index (FWI) [20,21] and the National Fire Danger Rating System (NFDRS) [19], both were not tested due to unavailability of climate data for the study area to assess them.

\section{Material and Methods}

2.1. The Study Area. The study area is located on the north coast of Bahia between latitudes $11^{\circ} 31^{\prime} \mathrm{S}$ and $11^{\circ} 58^{\prime} \mathrm{S}$ and longitudes $38^{\circ} 11^{\prime} \mathrm{W}$ and $38^{\circ} 38^{\prime} \mathrm{W}$. The plantations belong to the Bahia Specialty Cellulose company, which has approximately 100,000 ha planted with hybrid eucalyptus resulting from the cross Eucalyptus grandis (Hill ex. Maiden) $\times$ Eucalyptus urophylla (S. T. Blake) for cellulose production (Figure 1).

The meteorological station used in this work is placed at an altitude of $233 \mathrm{~m}$, latitude $11^{\circ} 50^{\prime} 42^{\prime \prime} \mathrm{S}$, and longitude $38^{\circ} 22^{\prime} 02^{\prime \prime} \mathrm{W}$, in the municipality of Inhambupe, Bahia. The climate of the town is semiarid with an average annual temperature of $24^{\circ} \mathrm{C}$, total rainfall of around $900 \mathrm{~mm}$ per year, and the rainy season from April to July [33]. The Atlantic Forest and Caatinga biomes are present in the region, and besides the plantation of eucalyptus, there are other minor forms of agricultural and some livestock is raised [34-36].

2.2. Data Processing. The relationship between the Forest Fire Danger Indexes and forest fire occurrence, obtained from the Bahia Specialty Cellulose company, was analyzed using daily meteorological data for 1 January 2002 to 31 December 2012, comprising a total of 4018 days (11 years) and forest fire occurrence data of the same period. Fire occurrence data were categorized in binary form, where the value " 1 " represents days with fire and " 0 " represents days without fire. Analysis of variance statistical analysis (ANOVA) was used to verify significant difference between the fire occurrence among the months and years.

The variables, air temperature at $1 \mathrm{pm}$ and $3 \mathrm{pm}$, relative humidity at $1 \mathrm{pm}$ and $3 \mathrm{pm}$, deficit saturation of the air, dew temperature, daily average wind speed, daily rainfall, and the number of consecutive days without rain, were quantified and applied in the following Forest Fire Danger Indexes: Angstron [37], Nesterov [38], Telicyn Logarithmic [39], FMA [24], Rodríguez and Moretti [40], and FMA+ [25].

To evaluate these six Fire Danger Indexes, the Heidke Skill Score (HSS) was used [41] (Table 1). The HSS measures the fractional improvement of the forecast over the standard forecast. The parameters from HSS that were chosen were the Skill Score (SS) and the Percentage of Success (PS), according to Sampaio [30], Nunes [25], and White [26] (1). The HSS 


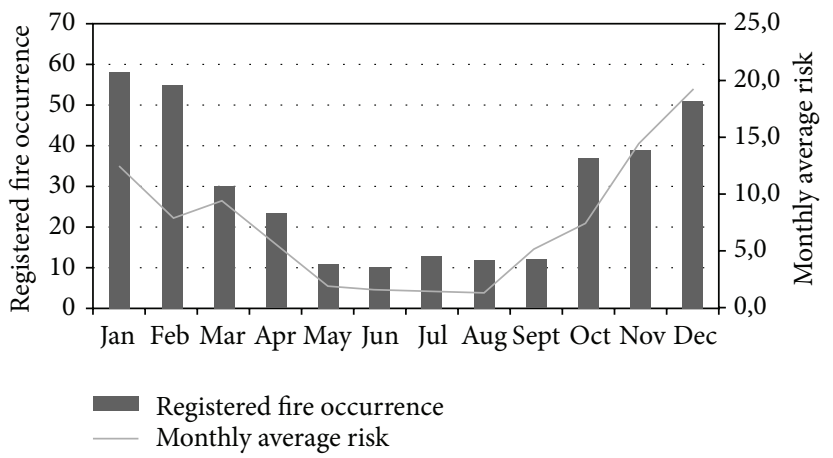

FIGURE 2: Monthly variation of forest fire risk according to the Telicyn Logarithmic Index and forest fires occurrences registered on eucalyptus plantation of Bahia Specialty Cellulose.

TABLE 1: Heidke Skill Score input table.

\begin{tabular}{lccc}
\hline \multirow{2}{*}{ Event forecast } & \multicolumn{3}{c}{ Event observed } \\
& Yes & No & Marginal total \\
\hline Yes & $a$ & $b$ & $a+b$ \\
No & $c$ & $d$ & $c+d$ \\
Marginal total & $a+c$ & $b+d$ & $a+b+c+d=n$ \\
\hline
\end{tabular}

methodology has been utilized and trusted by many authors (e.g., $[3,25,26,30,31,36,42,43])$ :

$$
\begin{aligned}
& \text { SS }=2 \times \frac{(a \times d)-(b \times c)}{[(a+c) \times(c+d) \times(a+b) \times(b+d)]}, \\
& \mathrm{PS}=\frac{(a+d)}{(a+b+c+d)} .
\end{aligned}
$$

\section{Results}

3.1. Fire Occurrence Distribution. Of the 4018 days analyzed, 351 days $(8.74 \%)$ had forest fire occurrence in the study area. The year of 2010 had the most fires, 49 , while 2008 had the least, 14. However, according to ANOVA test, the difference between those years was not significant $(F=0.86 ; p=0.57$ ). But when verifying months instead of the years, there was observed a significant difference among them $(F=3.67$, $p=0.16 * 10^{-3}$ ).

It was possible to separate the months in two distinct groups according to the forest fire occurrence: the group with higher fire occurrence, October, November, December, January, February, and March $(F=0.83 ; p=0.54)$, and the group with low fire occurrence, April, May, June, July, August, and September $(F=0.71 ; p=0.61)$ (Table 2).

3.2. Fire Danger Indexes Analysis. Applying the HSS to gauge the Fire Danger Indexes, it was determined that Telicyn Logarithmic Index is the best model to forecast fire occurrence in the study area, followed by the Angstron, FMA+, Nesterov, FMA, and Rodríguez and Moretti, respectively (Table 3).

According to the Telicyn Logarithmic daily-risk forecast, October, November, December, January, February, and March form the semester that presents the highest risk of fire occurrence, which is in accordance with the daily fire occurrence observation (Figure 2).

\section{Discussion}

Due to the size and diversity of climes in Brazil, several studies obtained different results when applying the Forest Fire Danger Indexes across the country; for example, Soares [29], Zaicovski et al. [44], and Deppe et al. [45] describe the FMA as the most appropriate model to forecast fire occurrence for the South region of Brazil, whose months of May, June, July, and August are those with most forest fire occurrence.

Borges et al. [31] determined that the FMA+ was the best index for the state of Espírito Santo, in Southeastern Brazil. Other studies in the Southeastern region, in the state of Minas Gerais, indicate the months June to October to be with most forest fire occurrence $[42,46]$ and May to September in Rio de Janeiro [47].

Narciso et al. [32] determined that the Nesterov Index is the most adequate for Mato Grosso do Sul, in the Midwest of Brazil, which presents June, July, August, and September as the months with most forest fire occurrence [48].

According to White and Ribeiro [27], the Angstron model functions best for Sergipe, in the Brazilian Northeast region, with December to February as the months with most forest fire occurrence. For the same geographic region (Northeast), but around $700 \mathrm{~km}$ up to North, Santana et al. [49] determined, for the state of Rio Grande do Norte, that the months August, September, October, and November present more forest fire occurrence.

These observations emphasize the climatic differences throughout Brazil and confirm what Bugalho and Pessanha [50] and Borges et al. [31] concluded: depending on the patterns of climatic variables in a study area, one Forest Fire Danger Index may predict better than another.

Besides assessing current available Fire Danger Index, new models can be created. White et al. [51], for example, developed a new index, the White model, due to the low accuracy of the existing models for the study area.

By determining or creating the best Forest Fire Danger Index for each region, better capitalization on the financial investments can be made in forest protection. 
TABLE 2: Amount of fire occurrence per year and month on eucalyptus plantation of the Bahia Specialty Cellulose company.

\begin{tabular}{|c|c|c|c|c|c|c|c|c|c|c|c|c|}
\hline Month & 2002 & 2003 & 2004 & 2005 & 2006 & 2007 & 2008 & 2009 & 2010 & 2011 & 2012 & Total \\
\hline $\operatorname{Jan}^{*}$ & 0 & 14 & 0 & 8 & 4 & 5 & 10 & 5 & 5 & 3 & 4 & 58 \\
\hline $\mathrm{Feb}^{*}$ & 0 & 9 & 1 & 7 & 10 & 4 & 3 & 11 & 0 & 3 & 7 & 55 \\
\hline Mar* & 1 & 3 & 0 & 4 & 0 & 0 & 1 & 10 & 3 & 4 & 4 & 30 \\
\hline Apr & 1 & 4 & 1 & 0 & 1 & 2 & 0 & 3 & 4 & 5 & 2 & 23 \\
\hline May' & 0 & 0 & 0 & 0 & 1 & 0 & 0 & 0 & 3 & 3 & 4 & 11 \\
\hline Jun' & 0 & 0 & 0 & 0 & 0 & 0 & 0 & 0 & 3 & 2 & 5 & 10 \\
\hline Jul' & 0 & 0 & 0 & 0 & 0 & 2 & 0 & 0 & 5 & 0 & 6 & 13 \\
\hline Aug' & 0 & 0 & 0 & 0 & 1 & 1 & 0 & 0 & 4 & 2 & 4 & 12 \\
\hline Sept & 1 & 2 & 0 & 2 & 0 & 0 & 0 & 0 & 1 & 4 & 2 & 12 \\
\hline Oct $^{*}$ & 9 & 1 & 4 & 2 & 2 & 2 & 0 & 0 & 9 & 4 & 4 & 37 \\
\hline Nov $^{*}$ & 7 & 0 & 7 & 9 & 0 & 8 & 0 & 0 & 4 & 1 & 3 & 39 \\
\hline Dec $^{*}$ & 10 & 2 & 11 & 4 & 1 & 10 & 0 & 0 & 8 & 4 & 1 & 51 \\
\hline Total & 29 & 35 & 24 & 36 & 20 & 34 & 14 & 29 & 49 & 35 & 46 & 351 \\
\hline
\end{tabular}

Note: ${ }^{*}$ Months with high fire occurrence.

Months with low fire occurrence.

TABLE 3: Values of the Skill Score and Percentage of Success for the Fire Danger Indexes evaluated in the study area.

\begin{tabular}{lcc}
\hline Indexes & SS & PS \\
\hline Telicyn Logarithmic Index & 0.10 & 0.59 \\
Angstron & 0.08 & 0.47 \\
FMA+ & 0.05 & 0.36 \\
Nesterov & 0.03 & 0.23 \\
FMA & 0.02 & 0.20 \\
Rodríguez and Moretti & 0.01 & 0.15 \\
\hline
\end{tabular}

\section{Conclusion}

Based on the results from this study, the Telicyn Logarithmic Index performed better for predicting daily forest fire occurrence in the study area. Also, it is possible to affirm with statistical significance that October to March are the months with higher forest fire occurrence.

Even though this study defined the best Forest Fire Danger Index for the study area, all the indexes tested presented poor result with a Skill Score $\leq 0.1$. This outcome supports the need for new studies using other indexes, such as the FWI or the NFDRS, or a development of a new Forest Fire Danger Index for the study area.

\section{Conflict of Interests}

The authors declare that there is no conflict of interests regarding the publication of this paper.

\section{References}

[1] G. R. van der Werf, J. T. Randerson, L. Giglio et al., "Global fire emissions and the contribution of deforestation, savanna, forest, agricultural, and peat fires (1997-2009)," Atmospheric Chemistry and Physics, vol. 10, no. 23, pp. 11707-11735, 2010.
[2] J. F. Santos, R. V. Soares, and A. C. Batista, "Perfil dos incêndios florestais em áreas protegidas no período de 1998 a 2002," Revista Floresta, vol. 36, no. 1, pp. 93-100, 2006.

[3] J. R. S. Nunes, R. V. Soares, and A. C. Batista, "Análise da fórmula de monte alegre alterada (FMA+) para o estado do Paraná," Revista Floresta, vol. 39, no. 3, pp. 473-484, 2009.

[4] A. F. Tetto, A. C. Batista, and R. V. Soares, "Zoneamento de risco de incêndios florestais para a Floresta Nacional de Irati, Estado do Paraná, Brasil," Revista Scientia Forestalis, vol. 40, no. 94, pp. 259-265, 2012.

[5] A. A. Brown and K. P. Davis, Forest Fire: Control and Use, McGraw-Hill, New York, NY, USA, 2nd edition, 1973.

[6] G. M. Byram, "Combustion of forest fuels," in Forest Fire: Control and Use, K. P. Davis, Ed., pp. 61-89, McGraw-Hill, New York, NY, USA, 1959.

[7] G. Certini, "Effects of fire on properties of forest soils: a review," Oecologia, vol. 143, no. 1, pp. 1-10, 2005.

[8] L. F. Debano, D. G. Neary, and P. F. Ffolliott, Fire's Effects on Ecosystems, John Wiley \& Sons, New York, NY, USA, 1998.

[9] S. J. Pyne, P. L. Andrews, and R. D. Laven, Introduction to Wildland Fire, John Wiley \& Sons, New York, NY, USA, 2nd edition, 1996.

[10] D. M. J. S. Bowman, J. K. Balch, P. Artaxo et al., "Fire in the earth system," Science, vol. 324, no. 5926, pp. 481-484, 2009.

[11] R. Smith and D. Lamont, Kimberley Bush Fire Burning Guidelines and Firebreak Location, Construction and Maintenance Guidelines, Fire \& Emergency Services Authority of Western Australia, Perth, Australia, 2007.

[12] A. B. Swengel, "A literature review of insect responses to fire, compared to other conservation managements of open habitat," Biodiversity and Conservation, vol. 10, no. 7, pp. 1141-1169, 2001.

[13] B. L. A. White, L. A. S. White, G. T. Ribeiro, and P. A. M. Fernandes, "Development of a fire danger index for eucalypt plantations on the northern coast of Bahia, Brazil," Revista Floresta, vol. 43, no. 4, pp. 601-610, 2013.

[14] J. H. Scott, Introduction to Wildfire Behavior Modeling, USDA Forest Service, National Interagency Fuels, Fire \& Vegetation Technology Transfer, 2012.

[15] M. Barbero, G. Bonin, R. Loisel, and P. Quézel, "Changes and disturbances of forest ecosystems caused by human activities in 
the western part of the mediterranean basin," Vegetatio, vol. 87, no. 2, pp. 151-173, 1990.

[16] D. C. Nepstad, A. Veríssimo, A. Alencar et al., "Large-scale impoverishment of amazonian forests by logging and fire," Nature, vol. 398, no. 6727, pp. 505-508, 1999.

[17] D. X. Viegas, G. Bovio, A. Ferreira, A. Nosenzo, and B. Sol, "Comparative study of various methods of fire danger evaluation in southern Europe," International Journal of Wildland Fire, vol. 9, no. 4, pp. 235-246, 2000.

[18] M. J. Schroeder and C. C. Buck, "Fire weather: a guide for application of meteorological information to forest fire control operations," in Agriculture Handbook 360, p. 229, USDA Forest Service, 1970.

[19] J. E. Deeming, R. E. Burgan, and J. D. Cohen, "The National Fire-danger Rating System-1978," Tech. Rep. INT-39, USDA Forest Service, Intermountain Forest and Range Experiment Station General, Ogden, Utah, USA, 1977.

[20] C. E. Van Wagner, "New developments in forest fire danger rating," Inform. Resp. PS-X-19, Canadian Forest Service, Petawawa Forest Experimental Station, 1970.

[21] C. E. van Wagner, "Structure of the Canadian forest fire weather index," Canadian Forestry Service Publication 1333, Petawawa Forest Experiment Station Chalk River, Department of the Environment, Ottawa, Canada, 1974.

[22] A. G. McArthur, Control Burning in Eucalypt Forests, vol. 80, Commonwealth of Australia Forestry and Timber Bureau, Canberra, Australia, 1962.

[23] A. G. McArthur, Fire Behaviour in Eucalypt Forests, vol. 107, Forestry and Timber Bureau, 1967.

[24] R. V. Soares, Determinação de um índice de perigo de incêndio para a região Centro-paranaense, Brasil [M.S. thesis], Instituto Interamericano de Ciências Agrícolas da OEA, 1972.

[25] J. R. S. Nunes, FMA+-Um Novo Índice de Perigo de Incêndios Florestais para o Estado do Paraná-Brasil [tese], Setor de Ciências Agrárias, Universidade Federal do Paraná, Curitiba, Brazil, 2005.

[26] B. L. A. White, Incêndios florestais no Parque Nacional da Serra de Itabaiana-Sergipe [Ph.D. Dissertation], Mestrado em Desenvolvimento e Meio Ambiente, Universidade Federal de Sergipe, São Cristóvão, Brazil, 2010.

[27] B. L. A. White and A. S. Ribeiro, "Análise da eficiência dos índices de perigo de ocorrência de incêndios florestais para o Parque Nacional Serra de Itabaiana, Sergipe," in Pensar a (In)Sustentabilidade: Desafios à Pesquisa, A. C. Santos, Ed., pp. 197-209, Redes Editora, Porto Alegre, Brazil, 2010.

[28] L. A. S. White, Análise espacial e temporal de incêndios florestais para o município de Inhambupe, litoral Norte da Bahia [dissertação], Mestrado em Ciências, Universidade Federal de Sergipe, São Cristóvão, Brazil, 2013.

[29] R. V. Soares, "Comparação entre quatro índices na determinação do grau de perigo de incêndios florestais no município de Rio Branco do Sul-PR," Revista Floresta, vol. 17, no. 1/2, pp. 31-36, 1987.

[30] O. B. Sampaio, Análise da Eficiência de Quatro Índices na Previsão de Incêndios Florestais para a Região de Agudos-SP [Ph.D. thesis], Setor de Ciências Agrárias, Universidade Federal do Paraná, Curitiba, Brazil, 1999.

[31] T. S. Borges, N. C. Fiedler, A. R. dos Santos, E. B. Loureiro, and R. G. Mafia, "Desempenho de alguns índices de risco de incêndios em plantios de eucalipto no norte do Espírito Santo," Revista Floresta e Ambiente, vol. 18, no. 2, pp. 153-159, 2011.
[32] M. G. Narciso, B. M. A. Soriano, O. Daniel, and F. A. Máximo, "Proposta de método para a seleção de indicador de risco de incêndio por região," Boletim de Pesquisa e Desenvolvimento, no. 113, 13 pages, 2011.

[33] A. T. Vieira, F. Melo, H. B. V. Lopes et al., Projeto cadastro de fontes de abastecimento por água subterrânea: diagnóstico do município de Inhambupe, Ministério de Minas e Energia, 2005.

[34] IBGE (Instituto Brasileiro de Geografia e Estatística), Cidades: Inhambupe. Infográficos, 2011, http://www.ibge.gov.br/cidadesat/ painel/painel.php?codmun=291370.

[35] Instituto Brasileiro de Geografia e Estatística (IBGE), Produção da Pecuária Municipal 2011, IBGE, Rio de Janeiro, Brazil, 2012.

[36] Instituto Brasileiro de Geografia e Estatística (IBGE), Produção Agrícola Municipal 2011, IBGE, Rio de Janeiro, Brazil, 2012.

[37] R. V. Soares, “Índices de perigo de incêndio," Revista Floresta, vol. 3, no. 3, pp. 19-40, 1972.

[38] V. G. Nesterov, Combustibility of the Forest and Methods for Its Determination, USSR State Industry Press, Moscow, Russia, 1949, (Russian).

[39] G. P. Telicyn, "Logarithmic index of fire weather danger for forests," Lesnoe Khozyaistvo, vol. 11, no. 1, pp. 1-58, 1970.

[40] N. Rodríguez and A. Moretti, "Índice de Peligro de Propagación de Incêndios Forestales," in Anais do 6th Congresso Florestal Argentino, Santiago del Estero, Argentina, 1988.

[41] P. Heidke, "Berechnung der erfolges und der gute der windstarkevorhersagen im sturmwarnungdienst," Geografika Annaler, vol. 8, pp. 301-349, 1926.

[42] V. G. Mafalda, F. T. P. Torres, and G. A. Ribeiro, "Eficiência de índices de perigo de incêndios baseados em elementos climáticos no município de Juiz de Fora-MG," in Proceedings of the Anais do 13th Simpósio Brasileiro de Geografia Física e Aplicada, Viçosa, Brazil, 2009.

[43] J. R. S. Nunes, R. V. Soares, and A. C. Batista, "Ajuste da fórmula de Monte Alegre Alterada (FMA+) para o Estado do Paraná," Revista Floresta, vol. 37, no. 1, pp. 1-14, 2007.

[44] M. B. Zaicovski, A. K. Guetter, and M. F. L. Quadro, "Sistema de monitoramento e previsão climática para o Risco de Incêndio Florestal (RIF) no Paraná," in Proceedings of the Anais do 10th Congresso Brasileiro de Meteorologia, pp. 3406-3412, Sociedade Brasileira de Meteorologia, Rio de Janeiro, Brazil, 2000.

[45] F. Deppe, E. V. Paula, C. R. Meneghette, and J. Vosgerau, "Comparação de índice de risco de incêndio florestal com focos de calor no Estado do Paraná," Revista Floresta, vol. 34, no. 2, pp. 119-126, 2004.

[46] F. T. P. Torres, G. A. Ribeiro, S. V. Martins, and G. S. Lima, "Determinação do período mais propício às ocorrências de incêndios em vegetação na área urbana de Juiz de Fora, MG," Revista Árvore, vol. 34, no. 2, pp. 297-303, 2010.

[47] C. B. Brandão, "Relações entre elementos climáticos e a ocorrência de incêndios em vegetação no Parque Estadual da Pedra Branca/RJ," in Anais do 16th Encontro Nacional de Geógrafos, Porto Alegre, Brazil, 2010.

[48] J. C. Silva, N. C. Fiedler, and G. F. Silva, "Uso da Fórmula de Monte Alegre na determinação dos períodos críticos de ocorrência de incêndios florestais na área de proteção ambiental do Gama Cabeça-de-Veado, Brasília, DF,' Revista Brasil Florestal, vol. 72, pp. 29-36, 2011.

[49] J. A. D. S. Santana, I. M. M. de Araújo, C. M. de Sena, A. S. Pimenta, and F. D. C. E. da Fonseca, "Determination of critical periods of forest fire occurrence in the seridó ecological station, Serra Negra do Norte-RN," Revista Caatinga, vol. 24, no. 1, pp. 43-47, 2011. 
[50] L. Bugalho and L. Pessanha, "Análise dos incêndios florestais em Portugal e avaliação do ICRIF (Índice Combinado de Risco de Incêndios Florestais)," Revista Territorium, vol. 16, pp. 155-163, 2009.

[51] B. L. A. White, L. A. S. White, G. T. Ribeiro, and P. A. M. Fernandes, "Development of a fire danger index for eucalypt plantations in the Northern Coast of Bahia, Brazil," Revista Floresta, vol. 43, no. 4, pp. 601-610, 2014. 

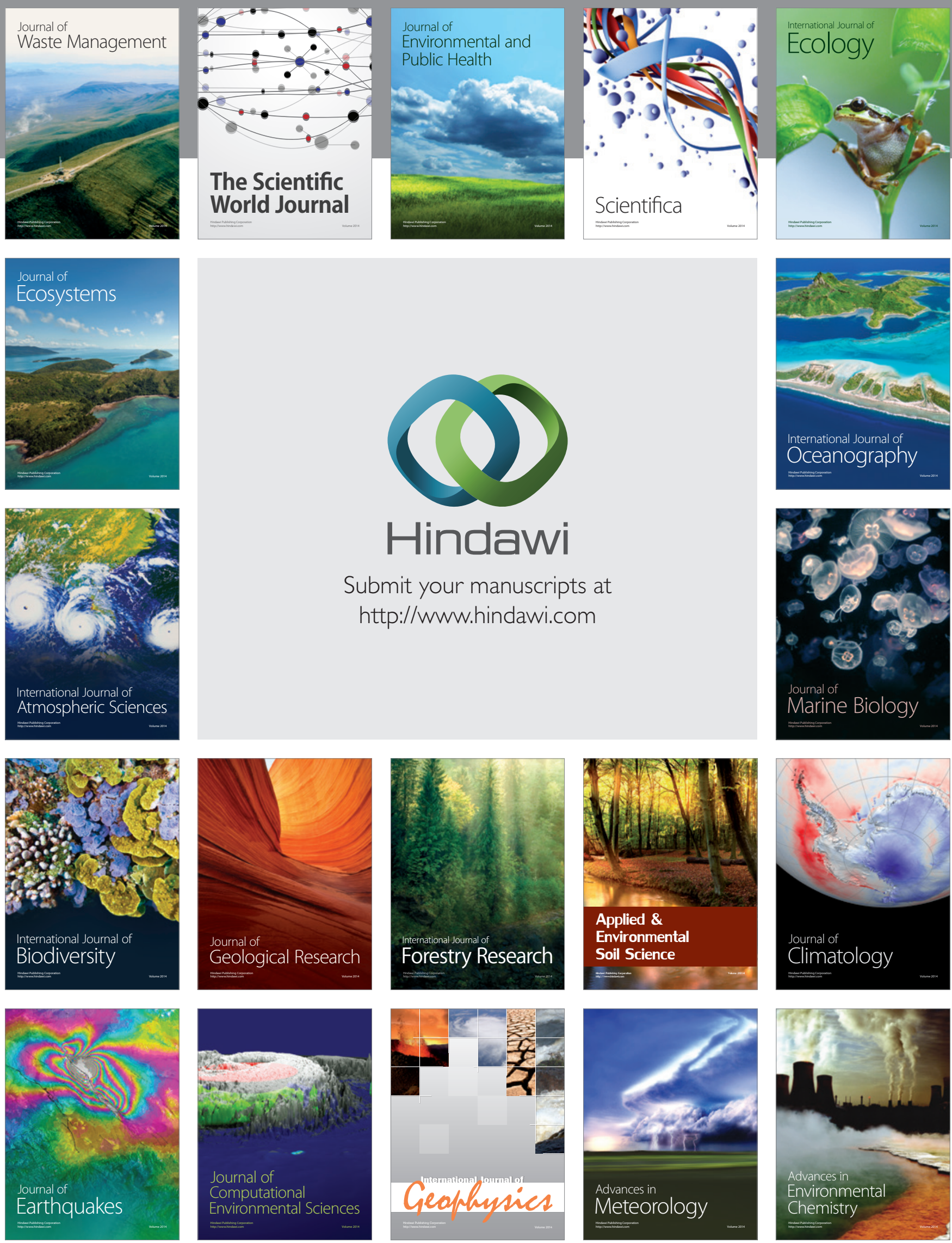